\title{
19
}

\section{The Official History of Australian Operations in Iraq and Afghanistan, and Australian Peacekeeping Operations in East Timor}

Craig Stockings ${ }^{1}$

Australia has commissioned official histories to record its experience on military operations five times over the last century: C.E.W. Bean in the First World War; Gavin Long and his team for the Second World War; Robert O'Neill for the Korean War; Peter Edwards for the Malayan Emergency, the Indonesian-Malaysian Confrontation and the Vietnam War; and David Horner for the peacekeeping, humanitarian assistance and other post-Cold War operations up to but excluding East Timor. I am humbled to be the next in line to carry this mantle, and this chapter outlines the scope and some of the challenges faced in writing this multivolume history. ${ }^{2}$

1 This chapter was written in 2018.

2 A version of this chapter was published as C. Stockings, 'A continuing tradition ... but a whole new ballgame: The Official Historian of Australian Operations in Iraq and Afghanistan, and Australian Peacekeeping Operations in East Timor', in Charles Bean: Man, Myth and Legacy, ed. P. Stanley, UNSW Press, Sydney, 2017, pp. 215-28. 
The effort to write the Official History of Australian Operations in the Middle East and East Timor has only just begun. Yet the history of this history project, even at this early stage, is important—for it frames what is a unique set of circumstances and contexts that surround this undertaking. There is no question that each of the five official histories that have preceded it have faced their own specific challenges and enjoyed their own individual advantages. At the same time, however, to me at least, the evolution of the process seems to have been incremental. I would put it to you at the outset that this series, dealing with a wide range of ADF operations both near and far from Australian shores, marks not a development or evolution of past experience so much as marking a new paradigm. Such a bold claim requires explanation — and I will certainly get there-but let me make one important early point. That is, this project is not, and cannot be, a repeat of past experience, updated for a new era. This is especially so in terms of the mechanics of research, and the environment in which my team labours. It is less so, of course, in terms of the tradition and philosophy behind past Australian official histories, which I seek to extend and enhance.

\section{History of a history}

Although talked about in a number of academic, public service and even political circles for some time, the real impetus for establishing a new Official History series came primarily through the tireless efforts of Emeritus Professor David Horner, the Official Historian of Australian Peacekeeping, Humanitarian and Post-Cold War Operations. Importantly, when Horner was appointed in 2004, Cabinet authorised the researching and writing of the history of all multinational operations and post-Cold War operations in which Australia has participated since 1947, excluding the recent operations in East Timor, Afghanistan and Iraq. Horner never stopped agitating for the inclusion of ongoing operations in Iraq, Afghanistan and East Timor to be taken within his or a subsequent Official History series. At every chance, including at the launch of the first volume of his peacekeeping series in April 2011, Horner spoke of the 'national disgrace' in the ongoing failure to capture and publicise the history of these operations. 
At this point wheels began to turn once more. Kevin Rudd, then foreign minister, gave his support at the book launch, and Horner was commissioned by the Australian War Memorial in September 2011 to draft a feasibility study of the possibility of writing a new Official History series capturing Australian involvement in Iraq and Afghanistan. This was completed by the following March and turned into a Cabinet submission by the War Memorial. Three times this submission was put forth, containing options either to expand the peacekeeping series to include East Timor and other operations up to 2006, or to raise a new series for Iraq and Afghanistan. The first submission was set aside with the fall of the Gillard Government, the second time put on ice when Rudd called an election, and lost to Prime Minister Tony Abbott.

There were compelling reasons, argued in the submission, for a new Official History to capture the large-scale and ongoing operations in the Middle East. The proximity and sensitivities surrounding these operations, it was argued, ought not to preclude it; after all, Bean's first volume appeared in 1921. A new series, written as close as possible to the events they were chronicling, would provide a public so interested, yet so disconnected from these events, with an authoritative account of Australian involvement.

This was all well and good, but there soon emerged a rather obvious spanner in the works. If the peacekeeping Official History series traced $\mathrm{ADF}$ operations up to and including the first Iraq War, and the series proposed in 2012 picked up the story of Afghanistan and the second war in Iraq, what then of East Timor? The blunt answer was not, of course, that Horner or the War Memorial had failed to consider operations in this theatre from 1999 to 2012. Indeed, the expansion of the peacekeeping series to include East Timor had been a submission in itself, wrapped up in broader 'omnibus' Cabinet submissions that had also called for a new Official History of Iraq and Afghanistan. At the same time, political signals were such that it was pointless to press the issue. Horner had been 'warned off. There were sensitivities and reputations mixed up in events in East Timor that were much closer to home than those in the Middle East—and this marks one of the challenges my project faces.

At last, in mid-2015, the government determined that a new multivolume Official History series should be produced to document Australian involvement in Iraq (2003-11), Afghanistan (2001-14) and East Timor (1999-2012). This then is the origin of my rather long title as 
Official Historian of Australian Operations in Iraq and Afghanistan, and Australian Peacekeeping Operations in East Timor. The division still stands. I have oversight of a series dealing with the Middle East, and a separate series dealing with East Timor-all under the banner of the title above. It is worth remembering, however, that the nature of the Official History project over which I now preside was a function of the long, complex process undertaken by Horner and others designed to get the project approved by the government. Political considerations first and foremost-historical considerations a distant second.

\section{My remit}

The national significance of this project speaks for itself. Australia's involvement in the Middle East has been complex and long-running. As many as 40,000 Australian Defence Force personnel are believed to have served or supported these deployments over 13 years of operations. Fortythree Australians died on active service in these theatres, and hundreds were wounded. Equally, Australia's involvement in East Timor from 1999 to 2012 was an instrumental part of East Timor gaining its independence. The INTERFET deployment of 1999-2000 was Australia's largest mission conducted under UN auspices and the largest overseas deployment since the Vietnam War. Taken in total, these operations constitute an important part of Australia's recent past, and one that clearly needed to be chronicled in an analytical and authoritative manner.

The formal offer of the position of Official Historian was made to me via a letter from the Prime Minister. The task was made quite clear. 'You will be responsible for delivering the Official History by July 2022.' Importantly, my commission provided for full access to relevant government files and records, authorised under official access conditions as set out in the Archives Act 1983, subject only to national security requirements and restrictions. The letter closed with a reminder-not that one was required-that Australia has a long tradition of producing official histories telling the story of Australians at war. 'The role of Official Historian is one of great national significance,' I was told. The shadows of not only Charles Bean but also of Gavin Long, Bob O'Neill, Peter Edwards and David Horner perched on my shoulder. They are there still. 


\section{Governance}

I did previously mention the significant differences between my project and those that have gone before. One key aspect in this regard is the type and level of governance imposed upon, and within, the project. I have been well funded for this task, to the tune of $\$ 12.6$ million. For this, I am of course most grateful. It is a level of resourcing not available to past official historians. The flip side of deep government and War Memorial investment in the project is, however, an extremely tight timeline and reasonably rigid governance frameworks. We have six years to complete these dual series, including the authorship of one of the volumes. My authors will each have five years to finish their respective volumes. This is a great deal tighter than any Official History project to date. It is a tough ask. Yet funding allows for each author to be assigned a fulltime research assistant. In terms of project management support, I have also employed a full-time project administrator/support officer. I am sure previous official historians are staggered by the staff and funds at my disposal, but I am sure they are equally staggered by the expectations of delivery. This is a different project from those that preceded it.

Perhaps another indication of the differences the project faces, labouring under considerable delivery expectations, are the administrative structures that surround it. The very first 'committee' established by me was the Official History Consultation Group. I raised this group for the sole purpose of providing expert external and scholarly advice on issues related to the Official History project, as they arose. The first task of this committee, when it met, was to examine the scope and volume structure of the official histories series as was approved in mid-2015 (largely unchanged from Professor Horner's earlier studies). The proposed volume structure was a single volume on East Timor, two volumes on Iraq and four on Afghanistan. The Consultation Group was unanimous in its conclusions that this was perhaps not the best spread of volumes and recommended changes. After all, as I mentioned earlier, this structure was a function of the long, complex process undertaken to get the Official History project approved. The question of the inclusion of East Timor in this series had been particularly vexed, and only agreed upon after approval was given to address both Iraq and Afghanistan. That is, a sixvolume study of the Middle East was envisaged before the question of East Timor was decided. East Timor was subsequently 'added' to the project as 
a pseudo-independent volume. At no time was the original scope of the Official History project the product of considered analysis or calculations of all three conflicts in a seven-volume, 'dual' series.

In this light, the Consultation Group recommended not one but two volumes for East Timor, a single volume for Iraq (which might need to spit into two in the future) and three for Afghanistan. A chronological approach was to be maintained. No stand-alone thematic volumes concerning single-service activities, or activities at the political and strategic level, were considered appropriate. You might have noticed a mathematical mismatch here in that this totals six volumes, not the seven originally approved. The recommendation to reduce the series from seven to six volumes was made on scholarly and historical grounds. Yet I am not shy to admit that it also resulted in close to $\$ 1$ million in salary savings that I knew, even then, would be required elsewhere. These recommendations were taken to the Memorial's senior management group, which approved them without question or complaint. The Memorial Council and the Department of Veterans' Affairs were informed of the outcome. The ease of passage of my recommendations in this regard gave me pause, and a sigh of relief. This was the type of support and the relationship between the project and its host institution that would allow us to succeed.

The second committee I raised is the Official History Records Access Steering Group. The purpose of this group is to act as an SES-level coordination body, above the 'operational' level of interaction between the project and select government departments, including Foreign Affairs and Trade, Prime Minister and Cabinet, Defence and the AFP. Other relevant agencies, particularly those with an intelligence and security bent, have requested direct and singular access to the project via the Official Historian and are not represented in this committee. More specifically, the steering committee will help identify the most appropriate methods by which necessary files and data can be made available, facilitate the flow of records into the project, and maintain protocols and pathways for project and external agency staff to work together. Last, it will act as a point of conflict resolution, to identify and resolve the difficulties that might arise with regard to the provision of appropriate and timely records to the Official History project. 


\section{Records}

A further indicator that this Official History project cannot and will not be a mirror image of past experience is that the nature of records and proximity to the conflicts under examination. I anticipate, in general and philosophical terms, that research data behind the volumes will come in two types, requiring two distinct historical methodologies. The first will be oral sources. A significant benefit of conducting this project so close to the conclusions of the operations under scrutiny is the wholesale availability of veterans. Acknowledging the perpetual challenges of oral sources, the nuances, explanations and 'stories' behind events will not appear on a documentary record. The gap will be covered by a comprehensive interviewing program.

Not surprisingly, the second source of data for this project will come from written, visual and hardcopy documentary sources in a range of formats-from Cabinet papers to emails. These will be sources primarily from uniformed and civilian Defence (including organisations like the Defence Intelligence Organisation and the Australian Signals Directorate), but, given the nature of these conflicts, important contributions will be required from those other agencies represented on the Records Access Steering Committee-DFAT, PM\&C and the AFP — as well as the Office of National Assessments, the United Nations, the International Committee of the Red Cross and so forth. Much Defence data exists on the 'Objective' records management system and is, more or less, searchable. In addition to Objective-accessioned material, other data, particularly from the earlier period (1999-2002), resides in more traditional repositories including the Army History Unit, Sea Power Centre - Australia, Office of Air Force History, various Defence headquarters, Defence Archives (Queanbeyan, Lidcombe and so on).

The procedure by which the project will access this type of informationacross all relevant government agencies, including Defence-has been settled upon by the Records Access Steering Group. First, the project will develop 'requests for file lists' (or RFFs) by volume (which equates to by theatre and time period). That is an initial batch of six RFFs will be written by the project. These RFFs will indicate the types and nature of data sought by the project and, in the case of Defence, where the project thinks such information might have been generated or held. Next, the project will submit RFFs to relevant agencies through their representatives on the 
Records Access Steering Group. On receipt of the project RFF, agencies will conduct internal record searches and prepare file lists, which will then be sent to the Official Historian for internal project distribution. For Defence, this will require collating file lists from multiple headquarters, commands and archives. Project authors will examine these lists, and determine a subset of files it wishes to view. This list will be returned to the relevant agency. On receipt of the returned file list, each agency will liaise directly with the project (through the Records Access Steering Group) to work out the details of access. In order to test the system described, an RFF based on the first East Timor (INTERFET) volume has recently been completed.

The final type of record relevant to the project is a large volume of data that has not been accessioned into Objective or Defence's legacy records management systems, nor catalogued into a physical collection within Defence, but rather data that sits unindexed and unaccessioned in a collection of hard drives returned from overseas, at Headquarters Joint Operations Command and other Defence repositories. This is a huge volume of data, appearing at upwards of 20 terabytes-literally millions of pages. These records are, at present, unsearchable and therefore of no use. However, Defence has initiated Project RORI; basically, a process to electronically 'ingest' these files, which stretch across the period from 1999 to the present, into Objective.

\section{My philosophy}

I think it appropriate to close with some comments on my personal outlook or philosophy as an Official Historian. I would begin by saying I suspect I differ very little from my predecessors in this regard. Official histories are, in many ways, a record of government actions and decisions based on government sources. They are a foundation and scaffold for future historians, and an accessible way for the public and the veteran community to gain insight into the operations and theatres under examination. This is particularly important today, given the serious disconnection between these 'wars' and the wider Australian public. I think it important too, given what I would describe as a significant mismatch between the public narrative of events in East Timor, Iraq and Afghanistan, and the true historical record. The perception of Australian activities and decision-making does not, in many ways, match wider understandings 
of those events. Here let me cast your minds back, for example, to the difficulties faced in gaining government approval for East Timor. There are reputations and legacies in play here that might not welcome a robust investigation and publication of the historical record. There are, possibly, institutional sensitivities at stake. There are also contemporary political and diplomatic considerations that might find a searching study of the recent past inconvenient. These are my challenges.

In response to problems of this type, let me offer a simple outlook that will certainly be captured in my brief to authors, and which represent a philosophical pillar of the project. We will not self-censor. We will include the good with the bad-frictions and mistakes are as valid a part of the historical record as triumphs. Successes in spite of institutional shortcomings enhance the legacy of those involved, not the reverse. We will write as we see it, and as the evidence trail indicates. If this outlook adds complications in future, then that will be dealt with then. The exception is, of course, security considerations. I have no problem with this at all. Others issues dressed up as security, however, might prove a different matter.

In terms of other aspects of Official History philosophy, one member of the author selection panel was inclined to ask potential candidates which of the past Official History series they would model their work most closely upon. It is a fair and interesting question. My answer would have been Gavin Long. The central reason here is that Long worked under the considerable weight of expectation set by Bean-so much so that his notebooks and correspondence abounds with efforts by actively serving officers to 'influence' him with an eye to how they might look in Bean 'mark two' series. Yet Long, particularly in To Benghazi, published in 1952, manages to my mind to weave in critiques and criticism where appropriate, without appearing cynical and within the context of what was expected of him. I have always appreciated this approach-a type of bravery in the context of his time. The only problem here is, perhaps, his over-subtlety. One needs to be aware of the problems to glean the full meaning of Long's tangential references. Most, I think, would have been lost on the wider public. To those within the tent, however, they would have stood out markedly. Given the framework, era and expectations he worked under, Long could never have been more explicit. I would hope to follow a similar line-with the caveat that with changing times and public expectations I need be much less discrete. 
Yet Long had his faults — or, more accurately, he made his concessions and compromises. Again, to use the example of To Benghazi, in an otherwise comprehensive and excellent account, and admittedly with the multifaceted pressures incumbent upon him, Long perpetuated many of the misguided wartime interpretations of events in North Africa. Interestingly, somewhat akin to Bean, he later conceded that the 'one objective of the Australian war histories is frankly a nationalistic one-to contribute to the statement of a national tradition'. ${ }^{3}$ Although far less interested than his predecessor in glorifying the ideal and achievement of the individual Australian soldier, Long nonetheless mirrored Bean's stressing of the primacy of Australian infantrymen on the battlefield. His conclusions are seriously undermined by a determination not to break the Anzac tradition of making Australian infantry, equipped with the individual and collective tools of inherited national character, the key determinant of victory. Long was unequivocal that the 'decisive work' in North Africa 'was done by ingenious and resolute foot soldiers'-making light of the all-important British logistics, gunners, machine-gunners and tank crews. ${ }^{4}$ Well aware that at the time of writing there were still sufficient survivors left to challenge this rather ahistorical argument, Long chose to land the first blow, careful to make use of a colourful and obscuring analogy: 'To ascribe the success either to tanks as the overwhelming arm (as some writers have done), or to the artillery', says Long, 'is to present Hamlet without the Prince'-poetic nonsense, I am afraid.

It is easy, however, to point fingers, and I admit freely and openly that the blow-torch has yet to be applied to me or my project. But at this early stage I chose not to follow this path. My aim is not a 'nationalistic' one-it is not celebratory or commemorative. It is historical, purely and simply. The day the project fails to engage with difficult and sensitive issues in a forthright manner is the day credibility is lost. There are simply

3 Originally quoted by A.G. Austin in his review of D. Dexter, The New Guinea Offensives, Australian War Memorial, Canberra, 1961, in Historical Studies, vol. 10, no. 39, 1962, pp. 392-3. See also J. Ross, The Myth of the Digger, Hale \& Iremonger, Sydney, 1985, p. 117; K.S. Inglis, 'The Anzac tradition', Meanjin Quarterly, vol. 24, no. 1, 1965, p. 32.

4 G. Long, Australia in the War of 1939-1945, vol. 1: To Benghazi, Australian War Memorial, Canberra, 1952, p. 205; F. Berryman, 'The Battle of Bardia: The AIF's First Battle in World War II', Directorate of Military Training, AHQ, Papers of Lieutenant-General Sir Frank Berryman, AWM PR $84 / 370$.

5 Long, To Benghazi, p. 205. 
too many veterans who know better - and that is not my style in any case. Yet I say this now, when philosophies are cheap and words simple to cast ... ask me again in six years time.

All of which brings me back to the question at the heart of the conference that led to the production of this book. That is, does Bean loom large for me and the most recent Official History series, or is he withdrawing into the shadows? Like any good historian, let me give an annoyingly qualified answer. As I have alluded to throughout this talk, my project and Bean's epic undertaking share little common ground in terms of process, context and the mechanics of researching and writing. In this regard, Bean feels of little use to me. He has little to tell. Even in terms of audience, times have changed dramatically since Bean's volumes were published. I feel the educated public and veteran community is more cynical, for example-in positive and negative ways. They are perhaps more willing to accept and digest criticisms of Defence and government decisions and actions than the past. I am in this regard perhaps freer to tell the blunt truth than Bean (or Long) would have been. On the other hand, there will be a portion of our readership so enamoured of the Bean-inspired connection between military achievement and national identity as to reject some of our more difficult findings and conclusions out of hand. Where Bean does perch on my shoulder, however, is less connected to the conduct of my project than to the weight of expectation I believe I place on myself. Bean made the conception of what an Official History is in Australia, and what it represents. It is that legacy I feel above all. 
This text is taken from Niche Wars: Australia in Afghanistan and Iraq, 2001-2014, edited by John Blaxland, Marcus Fielding and Thea Gellerfy, published 2020 by ANU Press, The Australian National University,

Canberra, Australia.

doi.org/10.22459/NW.2020.19 